\title{
Una Voz
}

A los diez años de su muerte

\begin{abstract}
A los diez años de la muerte de don Pedro Henríquez Ureña, su figura se nos ofrece ya rodeada de una levísima aureola. Sólo en la impertubabilidad del recuerdo podía aparecer, porque su espíritu era todo vida. Pero la larga distancia ha inmovilizado su imagen, $y$ un vago vapor de eternidad comienza a elevarse desde sus plantas a sus sienes.

En ciertos lugares, acaso en ciertos espíritus nada más, la pausada voz del maestro parece resonar como una especie de salmodia. Mas la salmodia se vuelca desde una fuente viva de sabiduría y el recuerdo traduce los sones en palabras y las palabras en ideas y las ideas en armoniosas y sutiles imágenes de cosas. Porque él no podía ver las cosas sino en armoniosas imágenes, en hermosas imágenes que le atrajeran por su ajustada representación y por su belleza formal.

Yo no lo puedo imaginar sino hablando muy lentamente, con un ritmo verbal que denotaba la exquisita y decantada prudencia que otorga la sabiduría, pero que no llegaba a ocultar la militante actitud crítica ni la ágil profusión de los pensamientos que entrechocaban en su mente. Acaso haya otras muchas imágenes posibles de él, pero acaso ninguna merezca perdurar como ésta lo merece.

En el coloquio, aquella voz suave hecha de ironía y bondad a un tiempo, se deslizaba fugitiva unas veces tras el impacto incontestable, o se demoraba otras en el infatigable análisis de las cosas, riguroso e imaginativo como un escolástico, fino y sensible como un cortesano dieciochesco. Su voz no
\end{abstract}


estaba hecha para la imprecación, ni para la injuria, ni para el debate; estaba hecha para el trasiego de las ideas, para ofrecerlas y acogerlas como reflejos del espíritu, para modelar su cuerpo, para ceñir su talle, para peinar su cabellera. Era la voz de un artista de las ideas. Ninguna estructura dogmática lo contenía, ningún compromiso intelectual le imponía su yugo, ningún perjuicio lo atemorizaba. Medido en el andar, contenido y débil en el gesto, tenía una insospechada audacia en el pensamiento y un desusado valor moral para defenderlo. Era el suyo un pensar libre, y parecía casi siempre un puro pensar.

El maestro que había en él no solía hallar en la tribuna un sitial propicio. Quien sólo lo conociera allí, no sabría de él sino lo menos profundo. Su voz no estaba hecha para ambular por los espacios deshabitados ni su pensamiento para dispersarse entre fantasmas desconocidos. Era una voz humana hecha para oídos humanos, incapaz de estridencias ni de expresar sonidos para que descubrieran su significado a través de atmósferas impuras. El maestro crecía hasta alcanzar un aire socrático en el diálogo desapasionado, en el coloquio libre, a través del despliegue de los espíritus. Ciertamente, le era necesario sentir el retorno de sus ideas después de haber irisado las mentes, le apasionaba descubrir las metamorfosis del pensamiento en su vagabundeo a través de climas diversos, le sucedía la magia de su expresión cuando se independizaba del pensamiento que la engendrara.

Acaso fuera, en el fondo y por sobre todo, un temperamento estético, y acaso fuera el coloquio su obra más depurada. Parecía adivinarse en él la perpetua ilusión de que las ideas surgieran siempre revestidas de peplos griegos, sutilmente plegados, conformando los torsos y las caderas, pero luego libérrimos en sus caídas, como resistiendo delicadamente a todas las auras. Las ideas parecían valer a sus ojos cuando reflejaban armonías profundas, de esas que su espíritu intuía en la meditación y reflejaba luego con vagas y esotéricas alusiones que eran, empero, hitos precisos en el encadenamiento de las ideas.

Porque la levísima aureola con que ya, a los diez años de su muerte, parece rodeada la figura de don Pedro Henríquez. 
Ureña, está hecha del contraste entre lo ilusorio y lo real, entre lo impreciso y lo definido que yacía en su espíritu y comienza a desprenderse de sus cenizas a la luz del recuerdo. Lo veo sumido en sus libros y sus papeles, lo veo precisando el contorno de un pensamiento, y lo veo al mismo tiempo persiguiendo quimeras profundas e irreales. Poeta y filósofo para sí, supo ser sabio para los demás. Extraño caso el suyo.

JOSÉ LUIS ROMERO

Buenos Aires, Argentina 
